\title{
The Effects of Metal Nanoparticles on the Mammalian Reproductive System
}

\author{
Parvin Lohrasbi ${ }^{1}$, Soghra Bahmanpour ${ }^{2}$ \\ ${ }^{1}$ Department of Reproductive Biology, School of Advanced Medical Sciences and Technologies, Shiraz University of Medical \\ Sciences, Shiraz, Iran. \\ ${ }^{2}$ Department of Anatomy and Reproductive Biology, Shiraz University of Medical Sciences, Shiraz, Iran. \\ Corresponding author. E-mail: bahmans@sums.ac.ir Tel. / Fax: +987132304372
}

Received: Apr. 10, 2021; Accepted: May 16, 2021; Published: Oct. 29, 2021

Citation: Parvin Lohrasbi, Soghra Bahmanpour, The Effects of Metal Nanoparticles on the Mammalian Reproductive System. Nano Biomed. Eng., 202I, I3(4): 344-363.

DOI: 10.5101/nbe.v13i4.p344-363.

\begin{abstract}
Due to the increasing use of nanoparticles in medical and industrial fields, concerns are growing about the toxicity of them to the body organs especially the reproductive system. In this review, the effect of metal/metal oxide nanoparticles on the mammalian reproductive system was discussed. Nanoparticles are typically toxic to both males and females, depending on their types, administration method, exposure duration, and surface modification. Regarding the embryo, it was also found that the effect of nanoparticles depends on the embryonic stage exposure during development. However, some nanoparticles, depending on the dose and time of administration, not only did not have toxic effects, but also strengthened the reproductive system and increased its efficiency. As the mode of interaction, penetration, and mechanism of nanoparticles action in the reproductive system is unclear, this review highlights the importance of additional tests in these cases.
\end{abstract}

Keywords: Metal nanoparticles, Mammalian, Reproductive system, Toxicity

\section{Introduction}

Today, metal nanoparticles have attracted special attention in biomedicine and industry due to their unique thermal, magnetic, optical, and biological properties. So far, there are about 2,000 products containing nanoparticles in the market, including antibiotics, food, textile, sports, and electronics industries, and the number of these products is increasing daily [1]. Despite the widespread use of nanoparticles in various fields, increasing human exposure to them has raised concerns about their toxicity to the environment and biological systems. Nanoparticles can enter the body through different ways such as inhalation, ingestion, and skin contact; then, via crossing biological barriers, they affect different organs including reproductive system (Fig. 1). Due to the large surface-to-volume ratio of nanoparticles, they are chemically highly reactive, and can easily enter the cells and damage different tissues, mainly by producing reactive oxygen species (ROS) and causing oxidative stress [2]. Mammalian gametes (spermatozoa and oocyte) and growing embryos are highly vulnerable; therefore, they are protected by some barriers including blood-testis barrier (BTB), theca cells, granulosa cell layers, zona pellucida (ZP), and placental barrier [3]. However, various nanoparticles have been shown to cross biological barriers, such as the blood-brain barrier (BBB); hence, their crossing through the BTB seems probable. It has been shown that metal nanoparticles can cross the BTB due to their small size as well as the production 


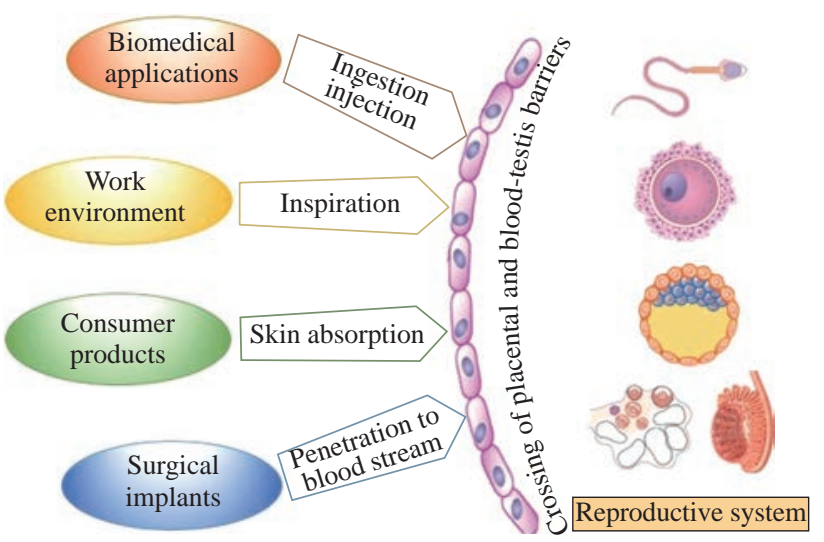

Fig. 1 The main sources and ways of mammalian reproductive systems exposure to metal nanoparticles.

of an inflammatory response that compromises the integrity of this barrier and induces testicular toxicity $[4,5]$. These nanoparticles reduce the expression of tight-junction proteins (Connexin-43, ZO-1, Occludin, Claudin) between Sertoli cells forming BTB by increasing ROS production, thus leading to DNA damage and cell cycle arrest in the sperm cells [6]. Nanoparticles can possibly affect hormone secretion in two ways: 1) crossing the blood-brain barrier, reaching the hypothalamus and pituitary gland secretory cells and altering the secretion of gonadotropin-releasing hormone $(\mathrm{GnRH})$, luteinizing hormone $(\mathrm{LH})$, and follicle-stimulating hormone (FSH); therefore, they affect normal ovarian estrogen and progesterone (P4) secretion; 2) entering the ovary through the circulation and accumulating in theca and granulosa cells, thereby affecting steroidogenesis. These events can lead to abnormal oocyte and ovarian disease (Fig. 2) [3]. About the placental barrier, an excellent review published in 2016 summarized the latest developments in this field. They tried to find out the properties of nanoparticles that cause them to cross the placenta. Smaller particles show more ability to cross the barrier. However, they observed this effect for all the studied models regardless of the species or experimental design; the cut-off size was significantly different (i.e. the range of nanoparticles size for crossing the placental barrier was different). The researchers concluded that materials of nanoparticles might be responsible for this finding, but for the other two properties, nanoparticle's charge and surface-coating, no clear trend was found, which is probably due to the poor design of the study. In addition to nanoparticle properties, embryonic/placental maturation can also play a role in nanoparticle transfer. In mice, for example, a vital window exists for transfer of gold nanoparticles from the placenta between 9.5 and 11.5 days of gestation. Surprisingly, it has not yet been carefully studied whether nanoparticles can systematically reach and penetrate the ovaries or follicles, but given the above data, this seems like a plausible scenario $[7,8]$.

As the reproduction, including fertilization and embryo development, is essential for species survival, the general concerns about nanoparticle toxicity in the reproductive system studies will be a huge problem.

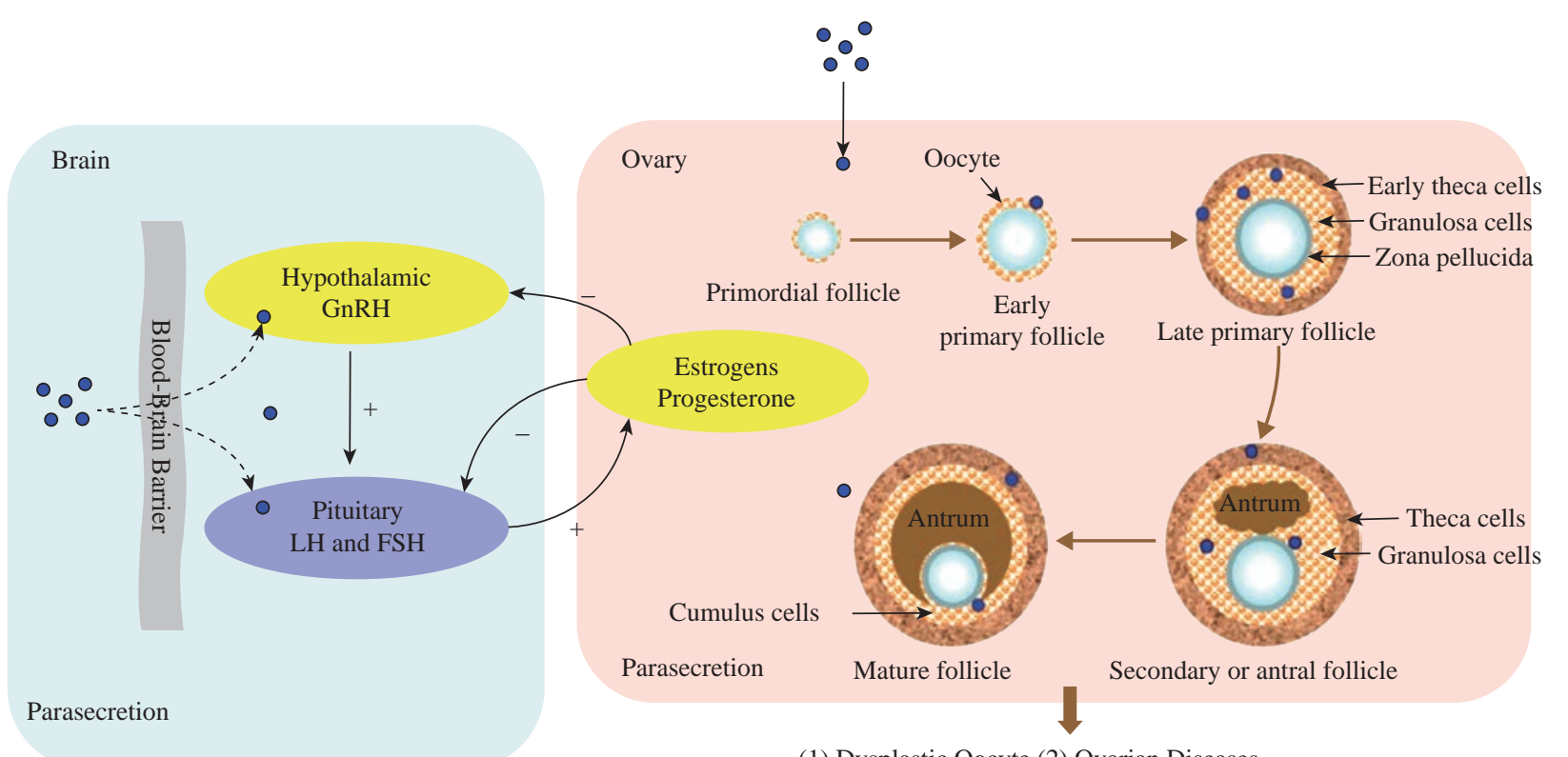

(1) Dysplastic Oocyte (2) Ovarian Diseases

Fig. 2 The effects of nanoparticles (NPs) on hormone secretion (Reprinted under the authority of Hou et al. Copyright (2017) Oncotarget) [3]. 
In this review, the in vivo and in vitro effects of metal/ metal oxide nanoparticles on the male and female mammalian reproductive systems were discussed. The mechanisms of nanoparticles action and interaction with the reproductive system were also emphasized at the cellular and molecular levels.

\section{Silver Nanoparticles}

Numerous shapes of silver nanoparticles can be constructed depending on their application. Commonly used silver nanoparticles are spherical, but diamond, octagonal, and thin sheets are also popular. Ag NPs are widely used as an antibiotic agent in textiles, wound dressings, medical devices, and appliances such as refrigerators and washing machines. The properties of silver nanoparticles applicable to human treatments are under investigation in laboratory and animal studies, assessing their potential efficacy, toxicity, and costs. We have reviewed the effects of silver nanoparticles on the reproductive system. [9].

Cytotoxic and genotoxic effects of different concentrations $(10 / 50 / 100 \mu \mathrm{g} / \mathrm{mL})$ of silver nano $(20 \mathrm{~nm})$ and submicron (200 nm) particles, and titanium dioxide nanoparticles $\left(\mathrm{TiO}_{2} \mathrm{NPs} ; 21 \mathrm{~nm}\right)$ in the testicular cells were examined. The researchers exposed Ntera2 (NT2, human testicular embryonic carcinoma cell line) and primary testicular cells from C57BL6 mice of wild type (WT) and 8-oxoguanine DNA glycosylase knock-out (KO, mOgg $1^{-/}$) genotype to the particles. The metabolic activity of the cells, cell death, DNA damage, and cytokines levels (IL-8/MIP2 , IL-6, and TNF- $\alpha$ ) was evaluated. The results showed higher levels of toxicity and cytostatic in Ag NPs (especially $200 \mathrm{~nm}$ ) than $\mathrm{TiO}_{2} \mathrm{NP}$ in the studied cells (primary testicular cells and NT2 cell line), leading to apoptosis, necrosis, and decreased proliferation in a concentration and time-dependent manner. Also, primary testicular cells in mice were found to be more sensitive to nanoparticles than NT2 cells. In general, both types of nanoparticles are likely to have effects on reproduction and human health. Besides, this study showed that not only the NP size, but also the cell type could be a limiting factor in their toxicity [10].

The effect of Ag NPs (20 nm, spherical) on the somatic (TM4) and germ cells derived from male and female mice was investigated. The experiment was performed both in vitro $(0,3.0625,6.125,12.5$, 25 and $50 \mu \mathrm{g} / \mathrm{mL}$ ) on the Sertoli and granulosa cells and in vivo (0.5 and $1.0 \mathrm{mg} / \mathrm{kg})$ in male and female mice, and silver-treated cells were used as the positive control. The results showed that Ag NPs induced toxicity in TM4 and granulosa cells after $24 \mathrm{~h}$. Also, it was found that this nanoparticle can lead to the formation of autophagosomes (large numbers of vesicles) and autolysosomes in the Sertoli cells due to cellular uptake of Ag NPs. Ag NPs also increased ROS production and induced apoptosis by regulating the mitochondrial pathway via enhancing the release of Bax from the cytosol to the mitochondria through increased release of cytochrome c. Moreover, Ag NPs affected the signaling of the molecules involved in apoptosis (Egfr/Akt/Erk/P53), leading to a decrease in p-Akt levels and an increase in the levels of p-Erk and p-p53. In vivo studies also showed a significant increase in the expression of pro-inflammatory cytokines such as TNF- $\alpha$, interferon $\gamma, 6,1 \beta$, and monocyte chemoattractant protein-1. Histopathological studies to detect the potency of Ag NPs to penetrate the blood-testicular barrier and enter the reproductive tissue, as well as its effect on the ovaries and follicles, revealed a significant lack of male and female germ cells. Overall, this study showed the negative effects of Ag NPs with a mean size of $20 \mathrm{~nm}$ on reproduction [11].

Treatment of male mice with $0.4 \mathrm{~mL}$ suspension of silver nanoparticles (50 nm, spherical), at a dose of $10 \mathrm{mg} / \mathrm{kg} / \mathrm{bw}$ for 35 days, leads to testicular weight loss, increased number of dead and abnormal sperms, decreased serum testosterone as well as irregularity, deformity, atrophy, degeneration, and necrosis in the epithelial cells of the seminiferous tubule. According to this study, Ag NPs induce these changes in the testis and sperm by penetrating the BTB [12].

In another study, the effect of different concentrations of Ag NPs (30, 125, and $300 \mathrm{mg} / \mathrm{kg}$ ) on sperm parameters, sperm chromatin integrity, and testicular tissue of rats was evaluated by intraperitoneal injection (for 21 days). The results showed the dosedependent effects of Ag NPs. A high dose, Ag NPs (300 mg/kg) reduced sperm count, sperm viability, testicular tubes, and altered sperm morphology. Also, 300 and $125 \mathrm{mg} / \mathrm{kg}$ doses decreased the number of spermatogonia, Sertoli, and Leydig cells, but sperm chromatin did not show a significant difference among different groups [13].

The effect of intratesticular injection of Ag NPs (220 $\mu \mathrm{L}$ of Ag NPs solution (0.46 mg Ag/mL) per testis) on rat reproductive parameters was investigated $(7,14$, 
28 , and 56 days after injection). The results showed a significant decrease in the sperm motility on day 7 (8.8\%) compared to the control groups (73.3\%), day 14 (86.0\%), day $28(68.2 \%)$ and day $56(90.0 \%)$. Besides, on day seven, the number of sperms with head and midpiece abnormality increased. On the other hand, no sperm was observed in the epididymis on day 7 , while on days 14 and 28, some sperms were observed. Therefore, intratesticular injection of Ag NPs resulted in severe but reversible effects on the sperm cells [14].

To investigate the effect of Ag NPs on the production of free radicals, antioxidant system, and sperm parameters, 30 rats in 6 groups were exposed to different doses of these nanoparticles $(0,10$, and $50 \mathrm{mg} / \mathrm{kg} / \mathrm{bw}$ ) for 7 or 28 days. The results showed a dose-dependent decrease in the sperm motility, sperm velocity, kinetic parameters, and a decrease in LH, FSH, and testosterone ( $\mathrm{T}$ ) hormone concentrations. Also, the concentrations of Malondialdehyde (MDA) and peroxide increased, but superoxide dismutase (SOD), catalase (CAT), and reduced glutathione concentrations decreased in the epididymis and testis. Taken together, these findings suggest that silver nanoparticles have detrimental effects on the sperm parameters in rats by disrupting hormonal balance and inducing oxidative stress in the testes and epididymis [15].

\section{Gold Nanoparticles}

Among metal nanoparticles, gold nanoparticles (Au NPs) have attracted attention due to their unique optical and physicochemical properties as well as biocompatibility in the biomedical field. These particles are easily functionalized and can be used for various medical purposes. Although gold is generally considered as a chemically inert material, many studies have shown that when it is used at the nanoscale, it has toxic effects on biosystems due to its tiny size and very large surface-to-volume ratio. These effects can depend on the size, shape, surface factors, administration method, and duration of exposure to nanoparticles [16, 17].

For the first time, Wiwanitikit et al. in 2009 investigated the effect of Au NPs (9 nm) on human spermatozoon. The results showed that Au NPs decrease the sperm motility and penetrate the heads and tails of the sperm cells and lead to their fragment [18].
Other studies have shown the effect of Au NPs on the sperm in animal models.

It has been shown that both acute and chronic intravenous injection of Au NPs (40 and $200 \mu \mathrm{g} / \mathrm{kg} /$ day, $1-100 \mathrm{~nm}$ ) leads to an increase in the sperms with abnormal tail and head, and a decrease in the sperm motility, depending on the dose and time compared to the control group. Cytochemical staining, such as $\mathrm{AB}$ (Aniline blue), TB (Toluidine blue), and CMA3 (Chromomycin A3), also showed an increase in histone residues and DNA fragmentation, and a decrease in mouse spermatozoa in groups treated with Au NPs [19].

However, in 2013, an interesting study by Tylor et al. showed that Au NPs $(10 \mu \mathrm{g} / \mathrm{mL})$ exert their inhibitory effects on the bovine sperm by adsorption on the sperm membrane rather than penetration. The results showed that oligonucleotide conjugated $\mathrm{Au}$ NPs reduce the sperm motility by binding to the spermatozoa membrane and free thiol residues reduction on the cell membrane. They also showed that ligand-free Au NPs decrease the ability of sperm to fertilize, possibly by agglomerate attachment to the sperm membrane, thereby interfering with the spermoocyte attachment and fertilization [20].

In another study, TM3 Leydig cell lines (derived from immature mouse Leydig cells) were cultured and then treated with different concentrations of Au NPs $(8.33 \mu \mathrm{M}$, $25.00 \mu \mathrm{M}$, and $62.50 \mu \mathrm{M}$ ). Cellular uptake, cytotoxicity, DNA damage, intracellular ROS production, apoptosis, cell cycle, and testosterone production were assessed. It was shown that Au NPs $(5 \mathrm{~nm})$ could penetrate to the endosomes/lysosomes of TM3 cells and induce autophagosomes, increase ROS, and stop the cell cycle in the S phase. In addition, after re-injection of Au NPs (0.17 and $0.50 \mathrm{mg} / \mathrm{kg} /$ day) in the BALB/c mouse model, the nanoparticles gradually accumulated in the testis as dose dependence and significantly reduced testosterone production in TM3 cells by inhibiting the expression of the 17 alpha-hydroxylase genes in the testis. The administration of these nanoparticles also increased the rate of epididymal sperm malformation and decreased the weight of epididymis, but they did not affect the sperm motility and concentration. Although these events did not directly affect fertility in the treated mice including copulation index, fertility index and gestation index, the mean number of offspring reduced at $0.5 \mathrm{mg} / \mathrm{kg}$ concentration, possibly due to fewer eggs or embryo death. In addition, these nanoparticles were administered for only 14 days, but longer or higher 
doses may reduce the sperm quality and ultimately affect fertility [21].

Moreover, studies have shown that the administration of a single dose of Au NPs ( $2 \mu \mathrm{g} \mathrm{Au} / \mathrm{gram}$ of body weight (BW), size 2, 15, and $50 \mathrm{~nm}$ ) to mice during pregnancy prevents embryonic development, which depends on the particle size and concentration. It was found that among the different sizes of Au NPs, only $15 \mathrm{~nm}$ nanoparticles downregulate the expression of germ layer markers such as SOX1, SOX3, and Nestin both at the mRNA and protein levels. Thus, these nanoparticles can probably prevent the differentiation of all three germ layers of the embryo, and leading to fetal resorption [22].

\section{Copper Nanoparticles}

Copper $(\mathrm{Cu})$ plays a role in maintaining the function of living organisms. Widespread use of this metal in the electrical industry, construction materials, water pipes, intrauterine contraceptive devices, etc. can lead to harmful effects. Although adequate amounts of copper are needed for embryo development, it has been shown that copper nanoparticles (Cu NPs) can cross the biological barriers due to their small size and lead to reproductive toxicity [23]. Cu probably affects both the male and female reproductive systems. Targets of $\mathrm{Cu}$ effects include the neuroendocrine system such as hypothalamic-pituitary gonadal (HPG) axis, sperm, embryo development, and testicular and ovarian functions. It has been shown that short-term in vitro administration of $\mathrm{Cu}$ leads to adverse effects on the ovarian cell organelles. Moreover, $\mathrm{Cu}$ can stimulate Insulin-like growth factor 1 (IGF-I) and progesterone release, and also induce the expression of peptides associated with proliferation and apoptosis [24]. Most studies have investigated the effect of Cu NPs on male reproduction.

The effect of Cu NPs (20-30 nm, 20 and $40 \mathrm{mg} / \mathrm{kg}$ for 3,6 , and 9 days) on the weight of some reproductive system organs and spermatozoa properties in albino male rats was evaluated. The results showed a significant decrease in the body weight due to disruption of different metabolic activities and an increase in sexual organs (testis, epididymis, seminal vesicle, and prostate gland) probably due to histopathological changes in these organs or in serum testosterone levels which play an important role in maintaining their structural integrity. Moreover, the percentage of sperm viability decreased, and the percentage of sperm abnormalities (such as deformed head, detached head, loss of head spine, coiled head, coiled tail, curved tail) and sperm concentration increased in a concentration and time-dependent manner. Thus, in general, this research showed the negative effects of $\mathrm{Cu}$ NPs on the male reproductive system activity [25].

The effect of polyvinylpyrrolidone (PVP)-coated $\mathrm{Cu}$ NPs (40 and $60 \mathrm{~nm}, 1$ and $2 \mathrm{mg} / \mathrm{kg} /$ day) on the reproduction of male rats was investigated. Treated groups showed a decrease in sperm density and motility and sex hormone (FSH, LH, Testosterone) levels. Also, biochemical parameters, cholesterol levels, and testicular proteins were improved, whereas glycogen and sialic acid content decreased. Therefore, $\mathrm{Cu}$ NPs altered the hormone and biochemical structure and also decreased fertility in male rats [26].

Possible effects of unsupported $\mathrm{Cu}$ NPs [spherical $(2.88 \mathrm{~nm})$, triangular $(1.27 \mathrm{~nm})$, hexagonal (1.81 $\mathrm{nm})]$, and supported spherical Cu NPs by titanium, zeolite $\mathrm{Y}$, and activated charcoal were examined in the porcine ovarian granulosa cells. For this purpose, the researchers evaluated the cell viability, cell proliferation (Proliferating cell nuclear antigen (PCNA) accumulation), apoptosis (Bax protein accumulation), and release of steroid hormones (progesterone, testosterone, and 17-beta estradiol). The results were as follows: Hexagonal $\mathrm{Cu}$ NPs reduced the cell viability, and other $\mathrm{Cu}$ NPs increased it. Unsupported spherical and hexagonal Cu NPs and spherical Cu NPs/ titanium decreased the PCNA accumulation. Apoptosis increased under $\mathrm{Cu}$ NPs/zeolite $\mathrm{Y}$, while other $\mathrm{Cu}$ NPs (except hexagonal Cu NPs) decreased it. Besides, $\mathrm{Cu}$ NPs/titanium dioxide inhibited the release of all steroid hormones, but Cu NPs/charcoal stimulated it. Therefore, the results showed a direct effect of $\mathrm{Cu}$ NPs on the ovarian cell function depending on their shape and support [27].

\section{Iron Nanoparticles}

Today, iron nanoparticles (Fe NPs) have attracted special attention in various industries due to their physicochemical properties, high catalytic activity, high magnetism, and low toxicity. Applications such as magnetic resonance imaging (MRI), drug delivery, gene therapy, cancer therapy, and cell sorting have been proposed for these nanoparticles in the biomedical field. Although Fe NPs are generally considered as 
low-toxicity nanoparticles, studies show that they are more likely to produce ROS, due to their high catalytic activity and Fenton-like reaction which results in oxidative damage to biomolecules. This raises many concerns about the reproductive systems [28, 29].

Early studies were conducted on the effect of $\mathrm{Fe}_{2} \mathrm{O}_{3} \mathrm{NPs}$ with different surface charges in pregnant CD-1 mice in 2014. It was shown that polyethyleneimine (PEI)-coated iron nanoparticles with positive surface charges were more toxic to the fetus and mother than nanoparticles with polyacrylic acid (PAA) coating, while the core of both nanoparticles was $\mathrm{Fe}_{2} \mathrm{O}_{3}$ with a diameter of $12 \mathrm{~nm}$. In general, multiple exposures to positively charged PEIcoated nanoparticles significantly increases the postimplantation loss, reduces the maternal weight, cross the placenta, and accumulates in the fetal liver [30].

In this regard, another study was done on the shortterm and long-term administration effects of positively and negatively charged Fe NPs at low $(10 \mathrm{mg} / \mathrm{kg})$ and high (100 mg/kg) doses during the main organogenesis period (gestation day (GD) 8,9,10) of mice. This study also showed the effect of nanoparticle surface charge on toxicity. Interestingly, low-dose nanoparticles had not only no toxic effects on the mother and fetus, but also positive effects such as reducing fetal death and increasing litter size, which could indicate iron supplementation effects. The administration of high doses of nanoparticles increased fetal death in the later gestation (GD10) stage for PEI-coated nanoparticles and in the earlier stage (GD8) for PAA-coated nanoparticles. All treated groups with $100 \mathrm{mg} / \mathrm{kg}$ PEI-coated nanoparticles showed uterus or testis histological changes such as endometrial thickening and germ cell loss, regardless of the administration time [31].

Various studies show that uncoated Fe NPs can induce oxidative stress and apoptosis in the reproductive system and cause toxicity, while coating these particles with polymers and biological macromolecules can have different effects.

It was found that intraperitoneal injection of 25 and $50 \mathrm{mg} / \mathrm{kg} /$ week $\mathrm{Fe}_{2} \mathrm{O}_{3} \mathrm{NPs}(<50 \mathrm{~nm})$ for 4 weeks could increase the ROS, lipid peroxidation, protein carbonyl content, glutathione peroxidase activity, and nitric oxide levels and also induce apoptosis in the mice testis cells. Besides, pathophysiological lesions such as vacuolization, detachment, and shedding of germ cells were observed [32].
Another study was performed to investigate the effects of different concentrations of bovine serum albumin (BSA)-coated superparamagnetic iron oxide nanoparticles (SPIONs) $(10,25$, or $50 \mu \mathrm{g} / \mathrm{mL}$ ) on human steroid hormone receptor expression and granulosa cell viability. The results showed that the expression of these receptors, as well as the survival of granulosa cells, was not affected; therefore, this form of iron nanoparticles is both less toxic and more biocompatible [33].

It has shown that coating iron nanoparticles (5.3 $\mathrm{nm}$ ) with DMSA (dimercaptosuccinic acid) make these nanoparticles safe for the sperm and prevents the particles from penetrating the sperm. Bull sperms were incubated with different doses of these nanoparticles (0.03, 0.06, $0.015 \mathrm{mg} / \mathrm{mL})$. Sperm motility, acrosome integrity, cell membrane, sperm structure, and uptake of nanoparticles were assessed after 4 hours of exposure. No negative effects on motility, viability, and sperm structure were observed and nanoparticles were not able to penetrate the sperm [34].

The effect of iron nanoparticles on the cultured sheep ovarian tissue was investigated. After incubating the ovarian specimen with uncoated, silica-coated, and PEGylated silica-coated iron nanoparticles (with an $11 \mathrm{~nm}$ core and $10 \mathrm{mg} / \mathrm{mL}$ concentration), morphological structure, follicular viability, oxidative stress, and particle permeability were assessed. Due to PEG (polyethylene glycol) hydrophilicity, PEGylated nanoparticles reduced the penetration of particles into cells the and nanoparticles toxicity. Uncoated nanoparticles exert the most amount of oxidative stress due to their smaller size, more penetration into the cell, and more reactive surface, resulting in more tissue damage along with a further reduction of follicular cells [35].

\section{Zinc Nanoparticles}

Zinc ( $\mathrm{Zn}$ ) is a necessary biological element for many biochemical processes such as growth and reproduction. It is an important component of various proteins such as copper/zinc superoxide dismutase and maintains the integrity of the DNA structure and nucleic acid metabolism. Other roles of zinc include interference with DNA repair, transcription and translation processes; maintenance of germ cells; promotion of spermatogenesis; and regulation of sperm motility [36]. It has been found that zinc deficiency in male reproduction can lead to gonadal 
dysfunction, testicular weight loss, seminiferous tubules shrinkage, Leydig cells damage, and deficiency of sex hormone production [37, 38]. Zinc oxide ( $\mathrm{ZnO})$ is also an environmental substance that has different biological functions such as bio imaging and cancer detection. Zinc oxide nanoparticles (ZnO NPs) are used in the manufacture of solar panels, electronics devices, medicine, cosmetics such as sunscreens, drugdelivery, etc. [39]. Moreover, ZnO NPs are potent antibacterial and antioxidant agents that demonstrate their biomedical and industrial applications [40, 41] possibly in which they can protect reproductive tissue.

Several in vitro studies aimed at investigating the effect of ZnO NPs (in different concentrations and sizes) on the mouse Leydig cells, Sertoli cells and spermatocytes, showing dose and time-dependent effects of these nanoparticles. In general, these nanoparticles increased the levels of oxidant enzymes (such as MDA) and decreased the levels of antioxidant enzymes (such as glutathione (GSH)), thus increasing the production of ROS. These events led to an increase in apoptotic proteins and induced apoptosis in the sperm cells [6, 42, 43]. Other studies have been performed in vivo, which are described below.

In a study, the possible protective role of ZnO NPs $(<100 \mathrm{~nm})$ was investigated in nicotine-treated adult rats. Animals received $10 \mathrm{mg} / \mathrm{Kg} /$ day of $\mathrm{ZnO}$ NPs with $1 \mathrm{mg} / \mathrm{Kg} /$ day of nicotine. Parameters measured in this study included testicular and epididymal histological changes, viability and morphological changes of the epididymal spermatozoa, serum levels of FSH and LH hormones, oxidative stress parameters, and expression of steroidogenic enzymes. The results showed mild to severe changes in the testicular and epididymal structures and sperm morphological abnormalities in nicotine-treated rats. Besides, biochemical results showed a decrease in all measured parameters but an increase in MDA levels in these rats, indicating the deleterious effects of nicotine on the reproductive performance. On the other hand, treatment of these rats with $\mathrm{ZnO}$ NPs showed a significant improvement in the mentioned parameters by reducing oxidative stress and increasing steroidogenic enzyme expression [36].

One study examined the adverse effects of $\mathrm{ZnO}$ NPs $(30 \mathrm{~nm})$ on the male reproductive system, as well as their possible mechanism. For this purpose, male mice were treated with different doses of these nanoparticles (50, 150, $450 \mathrm{mg} / \mathrm{kg}$ ) orally for 14 days. The results showed a decrease in epididymal sperm count and serum testosterone levels along with increasing $\mathrm{ZnO}$ NPs dose. Also, histopathological damages such as germ cell atrophy and vacuolization were observed. According to this study, increasing the dose of $\mathrm{ZnO}$ NPs leads to enhanced expression of genes associated with endoplasmic reticulum stress (IRE1 $\alpha$, XBP1s, BIP, and CHOP); thus, they have destructive effects on the male reproductive system. These nanoparticles also lead to reproductive toxicity by increasing caspase-3 expression and possibly activating apoptosis [44].

In previous literature, the dose and time-dependent cytotoxic effects of $\mathrm{ZnO}$ NPs on the testis and male germ cells were investigated.

For the first time in a study, the cytotoxic effects of these nanoparticles (88 $\mathrm{nm}$, spherical) on the spermatogonia cells were evaluated to survey the cytoskeleton and nucleoskeleton changes in the GC-1 cells (mouse testicular-derived cells as a model of spermatogenesis). For this purpose, cells were cultured for 6 and 12 hours at different doses $(0,1,5,8,10,20$ $\mu \mathrm{g} / \mathrm{mL})$. The results showed that higher concentrations of $\mathrm{ZnO}$ NPs led to toxicity of the mouse spermatogonia by increasing intracellular ROS production, DNA damage, cytoskeleton and nucleoskeleton modification, and cell death. This event, in turn, jeopardizes the progression of spermatogenesis and, consequently, male fertility in a dose and time-dependent manner [45].

Studies on the effect of zinc oxide nanoparticles on the female reproductive system were limited as follows:

In a study, the effects of intraperitoneal injection of $0.1 \mathrm{~mL}$ of high and low doses of ZnO NPs (20 and 150 $\mu \mathrm{g} / \mathrm{kg}, 35 \mathrm{~nm}$ ) and iron oxide $\left(\mathrm{Fe}_{2} \mathrm{O}_{3} \mathrm{NPs}\right.$ ) (5 and 40 $\mathrm{mg} / \mathrm{kg}, 30 \mathrm{~nm}$ ) on LH, FSH, estrogen, and progesterone levels were investigated in 40 white female mice. Morphometric studies were also performed on the ovaries and ovarian follicles affected by these nanoparticles. Significant differences were observed in the levels of LH, estrogen, and progesterone in the experimental groups compared to the control group. The highest levels of LH (7.2 mIU) and estrogen (69.5 $\mathrm{ng} / \mathrm{mL}$ ) were observed in the low dose $\mathrm{ZnO}$-treated groups and the highest levels of progesterone (1.9 $\mathrm{ng} / \mathrm{mL}$ ) in the high dose $\mathrm{ZnO}$-treated groups. These results demonstrate the beneficial effects of low doses of $\mathrm{ZnO}$ on fertility improvement through increasing levels of reproductive hormones, while high doses of these nanoparticles decrease fertility. Morphometric 
studies did not show a significant difference between the mean diameter of different follicular phases in the low dose ZnO NPs treated group compared to the control group. However, the high dose of $\mathrm{ZnO}$ NPs significantly increased the diameter of the primordial follicles. Moreover, low and high doses of $\mathrm{Fe}_{2} \mathrm{O}_{3} \mathrm{NPs}$ significantly reduced the follicular phase diameter compared to the control group [46].

The effects of $\mathrm{ZnO}(5,15,25 \mu \mathrm{g} / \mathrm{mL})$ and $\mathrm{TiO}_{2}$ nanoparticles $(5,25,50 \mu \mathrm{g} / \mathrm{mL})$ on the growth, ultrastructure, and viability of ovarian antral follicles in female C57BL/6J mice were evaluated in vitro. For this experiment, antral follicles were cultured with these two nanoparticles for 96 hours. Toxicity of the ovarian follicles was induced by $\mathrm{TiO}_{2} \mathrm{NPs}$ through entry and accumulation in cells and increase in the follicular diameter, and by ZnO NPs via decreasing follicular diameter. Also, both nanoparticles led to degradation of cytoskeletal arrangement and ultrastructural changes such as incomplete transzonal projection and mitochondrial swelling [47].

\section{Nickel Nanoparticles}

Nickel has many applications in the industry due to its unique physical and chemical properties. Nickel nanoparticles (Ni NPs) are used in various fields, including biomedical drugs, magnetic materials, etc. Despite human and environment can be exposed to these particles, their effects have not been fully studied [48]. Effects on male and female fertility, miscarriage, malformations and birth defects are some of the impacts identified for nickel micro-particles (NiMPs) on reproduction, and nickel nanoparticles (Ni NPs) may also lead to reproductive toxicity.

To investigate the relationship between Ni NPs and reproductive toxicity, male and female rats were treated with different doses of Ni NPs $(5,15,45 \mathrm{mg} / \mathrm{kg} /$ day, size $90 \mathrm{~nm}$ ) and NiMPs (45 mg/kg/day) orally before mating, and treatment of female mice continued during pregnancy and lactation. In this study, the parameters such as sex hormone levels, sperm motility, histopathology, and reproductive outcome, etc. were evaluated. The results showed an increase in FSH and LH levels; a decrease in estradiol at doses 15 and 45; ovarian lymphocytosis; vasodilation and contraction; infiltration of inflammatory cells; and an increase in the apoptotic cells in the ovarian tissue in female rats. In male rats, gradual weight loss, epididymal weight gain relative to body weight, changes in sperm motility, and a decrease in FSH and testosterone levels occurred. Also, shedding of the seminiferous tubules' epithelial cells, tubal cell disorder, apoptosis, and cell death were observed in the experimental groups. Moreover, changes in reproductive index and breeds development were also identified [49].

In another study, after treating female rats with $\mathrm{Ni}$ NPs $(90 \mathrm{~nm})$, parameters such as ovarian ultrastructural changes, ROS levels, oxidant and antioxidant enzymes (SOD, CAT, MDA, nitric oxide (NO)), and factors associated with cellular apoptosis (mRNA expression of caspase-3, caspase-8, caspase- 9 and protein expression of Fas, Cyt c, Bax, Bid, and Bcl-2) were evaluated in the ovaries. The results showed swelling of the mitochondria, loss of mitochondrial cristae, enlargement of the endoplasmic reticulum, decreased SOD and CAT activity, increased ROS, MDA and NO levels, decreased expression of caspases 3, 8, and 9 mRNA, increased expression of Fas, Cyt c, Bax and Bid proteins, and decreased Bcl-2 protein expression. Therefore, Ni NPs may induce reproductive toxicity in rats by altering the ovarian ultrastructure and also by changing the oxidative stress/antioxidant balance, thus inducing the mitochondrial pathway of apoptosis and death receptors [50].

\section{Titanium Oxide Nanoparticles}

Due to their unusual optical properties, titanium dioxide nanoparticles ( $\mathrm{TiO}_{2} \mathrm{NPs}$ ) have many applications in various fields such as sunscreens, food production, food supplements, toothpaste, cosmetics, medicine, etc., but their safety and non-toxicity are still unclear [51, 52]. Titanium nanoparticles have been shown to have detrimental effects on the gametes and somatic cells in humans and animals.

In an in vitro study, it was found that $\mathrm{TiO}_{2} \mathrm{NP}$ caused a decrease in the mouse testis Leydig cells proliferative capacity and vitality, as well as an increase in the expression of sensitive oxidative stress marker, hemoxigenase-1, and regulatory factor of cholesterol transport into the mitochondria, steroid acute regulatory protein (StAR), thus affecting androgen production by the Leydig cells [53].

In vivo evaluation of the $\mathrm{TiO}_{2} \mathrm{NPs}$ effects on organs, especially the reproductive system in male mice, showed that high doses of $\mathrm{TiO}_{2} \mathrm{NPs}(500 \mathrm{mg} / \mathrm{kg}$ ) reduced the sperm density and motility, increased abnormal sperms and apoptosis in germ cells, and changed the level of 
gonadal hormones (T, estradiol (E2)), while low doses $(200 \mathrm{mg} / \mathrm{kg})$ did not show these effects [54].

Structural and functional analysis of the spermatogenic epithelium in rats after exposure to $\mathrm{TiO}_{2} \mathrm{NPs}$ (40-60 nm, rutile form) showed corrosive changes such as thinning, irregularity of layers, and non-attachment of the sperm cells to the basement membrane of spermatogenic epithelium (SE). Also, the study showed decreased cell proliferation and differentiation by altering some markers such as Ki-67 (a cell proliferation marker) and c-kit (a well-known stem cell marker). Thus, $\mathrm{TiO}_{2} \mathrm{NPs}$ can lead to impaired spermatogenesis by changing the male reproductive system structure and functional properties [55].

An interesting study looked at whether the airway exposure of the male mice (C57BL/6J) to $\mathrm{TiO}_{2} \mathrm{NPs}_{\text {by }}$ air (not orally or by injection) could affect the sperm count and serum testosterone levels. The procedure was performed, in which adult mice were induced with 63 $\mu \mathrm{g}$ of $\mathrm{TiO}_{2} \mathrm{NPs}$ intratracheally (once a week for seven weeks). This method was found to lead to pneumonia but had no effect on the testicular/epididymal weight, sperm count, and serum testosterone levels [56].

In vitro examination of the $\mathrm{TiO}_{2} \mathrm{NPs}(1$ and $10 \mu \mathrm{g} / \mathrm{L}$, 20-60 nm, irregular \& hemispherical) genotoxic effects in human sperm showed a significant loss of sperm DNA integrity and increase of DNA fragmentation after 30 minutes of exposure to $\mathrm{TiO}_{2} \mathrm{NPs}$. These nanoparticles also showed their genotoxicity potential in the human sperm by increasing intracellular ROS levels [57].

Previous studies have shown the toxic effects of these nanoparticles on the male reproductive system. The following are some studies on the effects of $\mathrm{TiO}_{2} \mathrm{NPs}$ on the female reproductive system.

One study found that titanium oxide nanoparticles accumulated in the ovaries after treating the mice with $10 \mathrm{mg} / \mathrm{kg} \mathrm{TiO}{ }_{2} \mathrm{NPs}$ (ranged from 208 to 330 nm (mainly $294 \mathrm{~nm}$ )) for 90 days. This event leads to some damages such as changes in the expression of functional genes (up-regulation of 223 genes and down-regulation of 65 ovarian genes), imbalance in the release of mineral elements and increased expression of the genes involved in the synthesis of estradiol such as Cytochrome P450 17A1 (CYP17A1). In addition, these nanoparticles reduced the levels of progesterone, fertility and pregnancy rate, and increased the oxidative stress [58].
Exposure of female mice to different concentrations of $\mathrm{TiO}_{2} \mathrm{NPs}(2.5,5$ and $10 \mathrm{mg} / \mathrm{kg})$ for 90 days by gavage resulted in a significant reduction in body weight, and a relative reduction in the ovarian weight. In addition, these nanoparticles caused inflammation and follicular atresia by altering the expression of cytokines (increasing TNF- $\alpha$, IL- $1 \beta$, IL-6, Fas, FasL and decreasing IGF-1, GDF-9), creating sex hormone imbalance (increasing estradiol, decreasing progesterone, $\mathrm{LH}, \mathrm{FSH}$, and Testosterone), and altering hematological and biochemical parameters. Together, these events led to ovarian damage and reduced fertility [59].

In another study, by examining the effect of different concentrations of $\mathrm{TiO}_{2} \mathrm{NPs}(12.5 \mu \mathrm{g} / \mathrm{mL}, 25 \mu \mathrm{g} / \mathrm{mL}$ and $50 \mu \mathrm{g} / \mathrm{mL}, 25 \mathrm{~nm}$ ) on follicular development and oocyte maturation in rats in vitro, it was found that $\mathrm{TiO}_{2}$ at $25 \mu \mathrm{g} / \mathrm{mL}$ or above reduced the number of viable follicles, the formation of antral follicles and the number of cumulus-oocyte cell complexes (COCs) [60].

Also, continuous exposure of female mice to 2.5, 5, and $10 \mathrm{mg} / \mathrm{kg}$ of $\mathrm{TiO}_{2} \mathrm{NPs}(5-6 \mathrm{~nm})$ for 30 days led to premature ovarian failure (POF) by altering the serum hormone levels (decreasing estradiol, progesterone, inhibin B, and increasing $\mathrm{LH}, \mathrm{FSH}, \mathrm{FSH} / \mathrm{LH}$ ratio, anti-Müllerian hormone (AMH) and thyroidstimulating hormone (TSH)), and autoimmune markers (free triiodothyronine (fT3), free tetraiodothyronine (fT4), anti-nuclear antibody (ANA) and anti-thyroid peroxidase antibody (TPO-Ab) [61].

In one study, intravenous injection of $\mathrm{TiO}_{2} \mathrm{NPs}$ (35 $\mathrm{nm}$ ) at a dose of $0.8 \mathrm{mg} / \mathrm{mouse}$ into pregnant mice resulted in uterine weight loss and increased fetal reabsorption levels, due to its ability to penetrate the placental barrier [62].

To investigate the effects of $\mathrm{TiO}_{2} \mathrm{NPs}$ on fetal development, pregnant mice were exposed to different concentrations of these nanoparticles (25, 50, and $100 \mathrm{mg} / \mathrm{kg}$ BW, $6.5 \mathrm{~nm}$ ) from gestational day 0 to 17 . Increased levels of titanium in the maternal serum, placenta and fetus led to a decrease in calcium and zinc content in the maternal serum, placenta and fetus, which may be responsible for maternal weight loss, placental and fetal weight loss, reduced number of live fetuses, decreased crown-rump length (CRL) as well as decrease in caudal length and an increase in the number of dead fetuses or resorption. Besides, exposure to $\mathrm{TiO}_{2} \mathrm{NPs}$ inhibited fetal skeletal 
development, including the absence of cartilage, decreased ossification, and increased the number of fetuses with dysplasia (Fig. 3) [63].

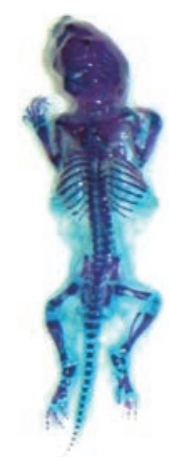

Control

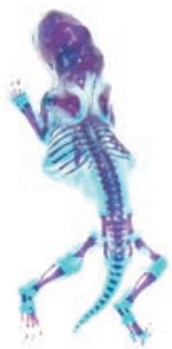

$25 \mathrm{mg} / \mathrm{kg} \mathrm{BW}$

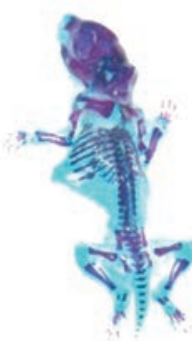

$50 \mathrm{mg} / \mathrm{kg} \mathrm{BW}$

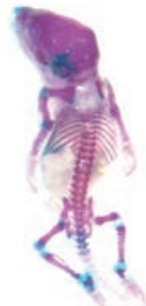

$100 \mathrm{mg} / \mathrm{kg} \mathrm{BW}$
Fig. 3 Mice fetal skeletal dysplasia after maternal exposure to different concentrations of $\mathrm{TiO}_{2} \mathrm{NPs}$. Blue color: cartilage; Purplish red: ossification; Red: incomplete ossification; BW: body weight (Reprinted under the authority of Hong et al. Copyright (2017) Dovepress) [63].

Also, it was found that exposing the pregnant mice to $\mathrm{TiO}_{2} \mathrm{NPs}$ ( 1 and $10 \mathrm{mg} / \mathrm{kg} /$ day, $<25 \mathrm{~nm}$ ) affected the placental development by disrupting the complex network of embryonic vessels, inhibiting proliferation, and inducing placental apoptosis through nuclear pyknosis, active caspase 3, increased Bax, and decreased Bcl-2 proteins expression [64].

These studies provided new insights into the effect of $\mathrm{TiO}_{2} \mathrm{NPs}$ on fetal mortality and malformation. Therefore, scientists recommend that $\mathrm{TiO}_{2} \mathrm{NPs}$ containing supplements should be avoided during pregnancy until the safety of it is proven.

\section{Cerium Nanoparticles}

Cerium (Ce) is a soft and silvery-white metal with ductility properties that is known as the second element in the lanthanide series. Cerium was first separated in the oxide form, which was called ceria, a term that is still used [65]. Cerium compounds are widely used as pharmaceuticals components [66]. Cerium oxide nanoparticles $\left(\mathrm{CeO}_{2} \mathrm{NPs}\right)$ are present in two oxidation states $\left(\mathrm{Ce}^{3+}\right.$ and $\left.\mathrm{Ce}^{4+}\right)$ [67]. These nanoparticles have various industrial applications, such as polishing agents [68], solar cells, and fuel catalysts [69]. Also, $\mathrm{CeO}_{2} \mathrm{NP}$ are used in biomedical fields because of some interesting features including the redox activity, free radical scavenging properties, antiinflammatory activity, etc., which can help maintain pro/antioxidant balance in the aging organism [70].
However, different studies have been performed about the effects of $\mathrm{CeO}_{2} \mathrm{NPs}$ on biological systems, such as the reproductive system, both in vivo and in vitro, their safety has not been fully investigated.

For the first time in 2015, a study was conducted to investigate the toxicity of $\mathrm{CeO}_{2} \mathrm{NPs}(0.01$ and 100 $\mathrm{mg} / \mathrm{L}$, ellipsoidal, $\sim 7 \mathrm{~nm}$ ) in reproduction. It was found that in vitro fertilization (IVF) in the culture medium containing very low doses of these nanoparticles $(0.01 \mathrm{mg} / \mathrm{L})$ in mice resulted in : a) damage to the sperm and oocyte DNA; b) decreased fertilization due to possible reasons such as genotoxic effects of nanoparticles on gametes, disruption of the interaction between gametes, and induction of oxidative stress by $\mathrm{CeO}_{2} \mathrm{NPs}$; c) no entry and accumulation of $\mathrm{CeO}_{2} \mathrm{NPs}$ in the cytoplasm of the sperm, oocyte, and embryo, and only accumulated around the plasma membrane of sperm and ZP of the oocyte [71].

In this regard, another in vitro study was performed on human sperm; it was found that these nanoparticles were not able to enter the sperm but induced inversely dose-dependent ( 0.01 to $10 \mathrm{mg} / \mathrm{L}$ ) damage to the sperm DNA. Therefore, very low doses of these nanoparticles led to genotoxicity [72].

The next study investigated the effect of different doses of $\mathrm{CeO}_{2}$ NPs $(0,44,88$, or $220 \mu \mathrm{g} / \mathrm{mL})$ during in vitro maturation (IVM) of the prepubertal bovine oocytes on embryonic development. After the oocytes matured in the culture medium containing $\mathrm{CeO}_{2} \mathrm{NPs}$, IVF was performed, and the zygotes were cultured for seven days. The results showed that these nanoparticles were not able to enter the cytoplasm of immature oocytes (germinal vesicle stage) and had no effect on the maturation of the nucleus or intracellular levels of ROS in the oocytes. These nanoparticles in low doses probably reduce the expression of apoptotic genes and stress responses in the oocyte cumulus cells. According to the findings of this study, the presence of low doses of $\mathrm{CeO}_{2} \mathrm{NPs}(44 \mu \mathrm{g} / \mathrm{mL})$ in the culture medium contributed to the maturation of the oocytes with poor developmental capacity. This concentration of $\mathrm{CeO}_{2} \mathrm{NPs}$ was also able to improve the quality of embryos by increasing the number of the inner cell mass (ICM) and trophectoderm cells and the development of embryos up to the blastocyst stage [73].

In another study, researchers investigated the effect of $\mathrm{CeO}_{2} \mathrm{NPs}$ on the oocyte meiotic maturation and follicular granulosa cell viability in young and old 
Balb/C and CBA mice in vivo. Balb/C mice received $45 \mathrm{mg} / \mathrm{kg}$ of $\mathrm{CeO}_{2} \mathrm{NPs}$ for three days, which had positive effects on the reproductive system, including an increase in the number of metaphases I and II oocytes within the follicles. Also, the results were accompanied by an increase in the number of living granulosa cells and a decrease in necrotic or apoptotic granulosa cells. Data from CBA mice also showed positive effects of $\mathrm{CeO}_{2} \mathrm{NPs}$ on the reproductive system in a dose-dependent manner. It was found that in old mice, these nanoparticles, as an anti-aging agent, were able to protect the granulosa cells against oxidative stress. Also, in these older mice, $\mathrm{CeO}_{2} \mathrm{NPs}$ increased the number of offspring born per delivery or litter size. According to these results, possibly $\mathrm{CeO}_{2} \mathrm{NPs}$ can be considered as an antioxidant agent by reducing the ROS content and oxidative stress level [74].

In an in vitro study, the mechanisms of interaction between $\mathrm{CeO}_{2} \mathrm{NPs}$ and germ cells were investigated for the first time. For this purpose, mature mouse oocytes were incubated with different concentrations of $\mathrm{CeO}_{2} \mathrm{NPs}(2,5,10$ and $100 \mathrm{mg} / \mathrm{L}$ ) and then the following parameters were evaluated: 1 ) physicochemical transformation of $\mathrm{CeO}_{2} \mathrm{NPs}$ in the culture medium; 2) ultrastructural interactions with follicular cells and oocytes; 3) genotoxic effects of $\mathrm{CeO}_{2} \mathrm{NPs}$ on the follicles and oocytes. The results showed that these nanoparticles were able to enter and accumulate in the follicular cells, while in the oocytes they accumulated only around the ZP. Moreover, the results showed DNA damage in follicular cells and dose-dependent damage to the oocyte DNA. According to the results of this study, it was hypothesized that at low concentrations of nanoparticles, the oocytes are indirectly immune to oxidative stress due to their dual defense system (follicular cells and zona pellucida). However, at high concentrations, these defense systems may not be able to adequately prevent DNA damage from induced oxidative stress [75].

In another study, to evaluate the toxicity of different doses of $\mathrm{CeO}_{2} \mathrm{NPs}(0,100,200$, and $300 \mu \mathrm{g} / \mathrm{kg})$ on the male reproductive system, Balb/C mice received the nanoparticles by intraperitoneal injection three times a week for five weeks. The results showed a decrease in hemoglobin levels, packed cell volume (PCV), red blood cell (RBC) count, and LH, FSH, and prolactin levels. At a dose of $100 \mu \mathrm{g} / \mathrm{kg}$, these nanoparticles reduced the testosterone level by $23 \%$, and at a dose of $200 \mu \mathrm{g} / \mathrm{kg}$, decreased FSH and LH and prolactin levels by $25 \%, 26 \%$, and $13 \%$, respectively. Also, all three doses increased the levels of the MDA enzyme and, on the other hand, decreased the activity of antioxidant enzymes and the levels of GSH and NO. Other results of this study included decreased motility and count of sperm, increased abnormal sperm, and degeneration of seminiferous tubules. Overall, $\mathrm{CeO}_{2} \mathrm{NPs}$ impair the testicular function by disrupting antioxidant/oxidant balance as well as endocrine suppression, according to the study [76].

To investigate the antioxidant properties of CeNPs at different doses (15 and $30 \mathrm{mg} / \mathrm{kg} /$ day), the researchers first induced toxicity effects in male Wistar rats through a pesticide called malathion. Malathion significantly reduces the count, viability, and motility of sperm by decreasing antioxidant capacity and thiol groups and increasing testicular MDA. Both doses of CeNPs improved the level of MDA and exert protective effects on the sperm by improving oxidative stress and increasing the sperm count, motility, and viability in the testes at $30 \mathrm{mg} / \mathrm{kg} /$ day dose [77].

The effects of chronic administration of $\mathrm{CeO}_{2} \mathrm{NPs}$ (20 and $40 \mathrm{mg} / \mathrm{kg}, \sim 27 \mathrm{~nm}$ ) orally was examined in male mice. Sperm parameters, sperm DNA integrity, daily sperm production (DSP), blood testosterone level, testicular cerium (Ce) element content, steroidogenic enzymes, as well as steroidogenic factor-1 (SF-1) gene/ protein level were evaluated. The results showed that these nanoparticles increase the content of Ce element in the testis and damage the sperm DNA, and reduce testicular weight, DSP and sperm motility. Besides, $\mathrm{CeO}_{2} \mathrm{NPs}$ disrupted the testosterone synthesis by decreasing the expression of steroidogenic enzymes and SF-1. Therefore, according to the study findings, long-term administration of $\mathrm{CeO}_{2} \mathrm{NPs}$ at doses above $20 \mathrm{mg} / \mathrm{kg}$ can impair the male reproductive function [78].

In another study, to evaluate the potential protective and antioxidant effects of CeNPs $(<25 \mathrm{~nm})$ in Fipronil (FIP)-treated male rats, a potent endocrine disruptor, these animals received $35 \mathrm{mg} / \mathrm{kg}$ body weight of these nanoparticles for 28 days. The results showed that CeNPs reduced the harmful effects of FIP on the testicular tissue by reducing lipid peroxidation, apoptosis, and inflammation, as well as increasing antioxidant activity [79].

A summary of all the studies covered in this review is shown in Table 1. 
Table 1 A summary of all the studies covered in this review. Abbreviations: NP, nanoparticle; bw, body weight; DNA, deoxyribonucleic acid; BTB, blood-testis barrier; GPx, glutathione peroxidase; GSH, reduced glutathione; MDA, malondialdehyde; NO, nitric oxide; CAT, catalase; SOD, superoxide dismutase; ROS, reactive oxygen species; Bcl-2, B cell lymphoma-2; Bax, Bcl2-associated X protein; Cyt c, cytochrome c; StAR, steroidogenic acute regulatory protein; CYP17A1, Cytochrome P450 17A1; T, testosterone; LH, luteinize hormone; FSH, follicular stimulation hormone; E2, Estradiol; SOX, sex-determining region Y-box; PCNA, Proliferating cell nuclear antigen; PEI, polyethyleneimine; PAA, poly (acrylic acid); BSA, bovine serum albumin; IVF, in vitro fertilization; IVM, in vitro maturation; ZP, zona pellucida; ICM, inner cell mass; COC, cumulus-oocyte cell complex; DMSA, dimercapto succinic acid; PEG, polyethylene glycol; SPION, Superparamagnetic Iron Oxide Nanoparticles; IRE1 $\alpha$, inositol-requiring enzyme $1 \alpha$; XBP1, X-box binding protein 1; BIP, binding protein; CHOP, homologous protein; PCV, packed cell volume; RBC, red blood cell; DSP, daily sperm production; SF-1, steroidogenic factor-1; POF, premature ovarian failure; AMH, anti- Müllerian hormone; TSH, thyroid-stimulating hormone; fT3, free triiodothyronine; fT4, free tetraiodothyronine; ANA, anti-nuclear antibody; TPO-Ab, anti-thyroid peroxidase antibody.

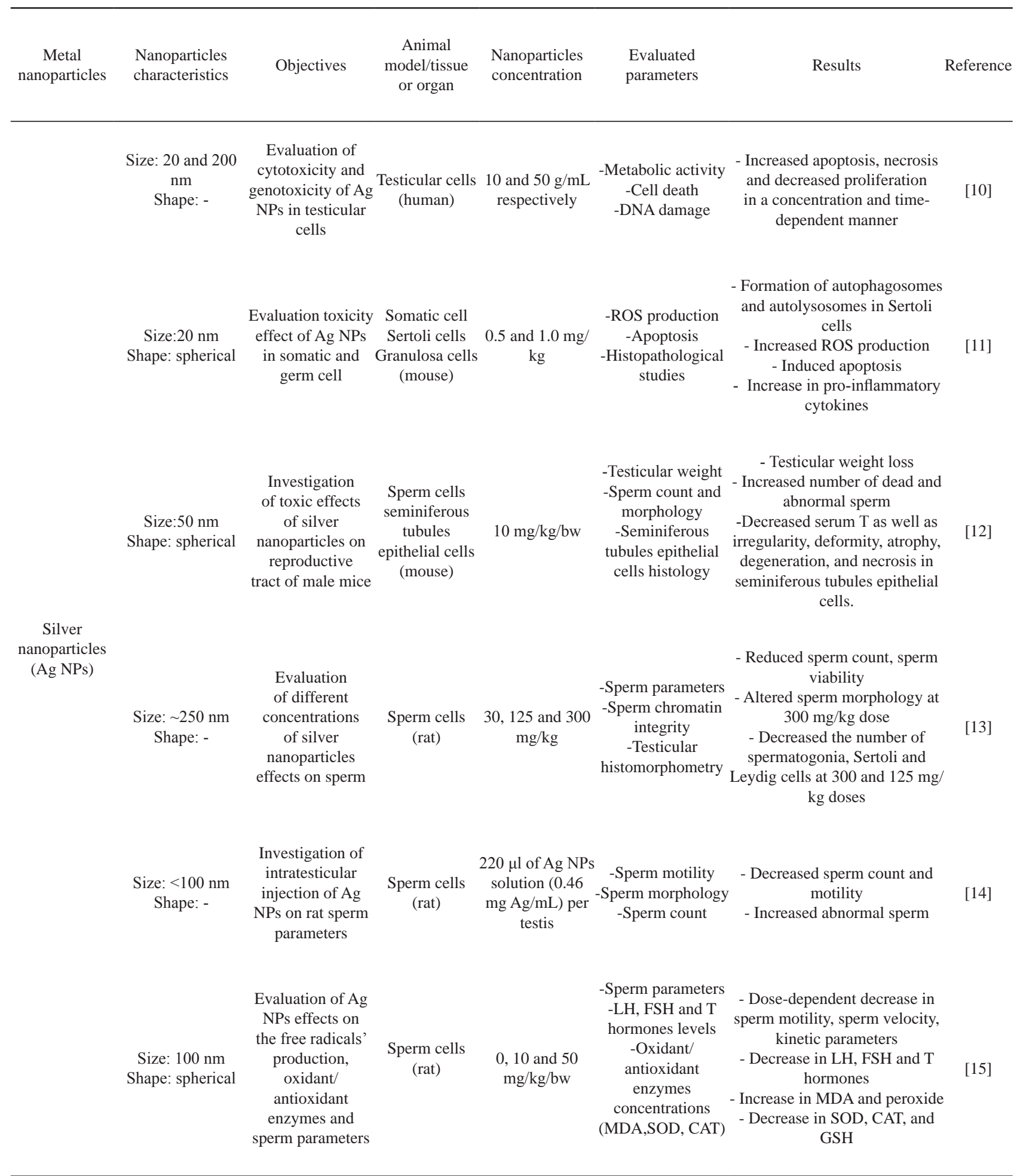


continued

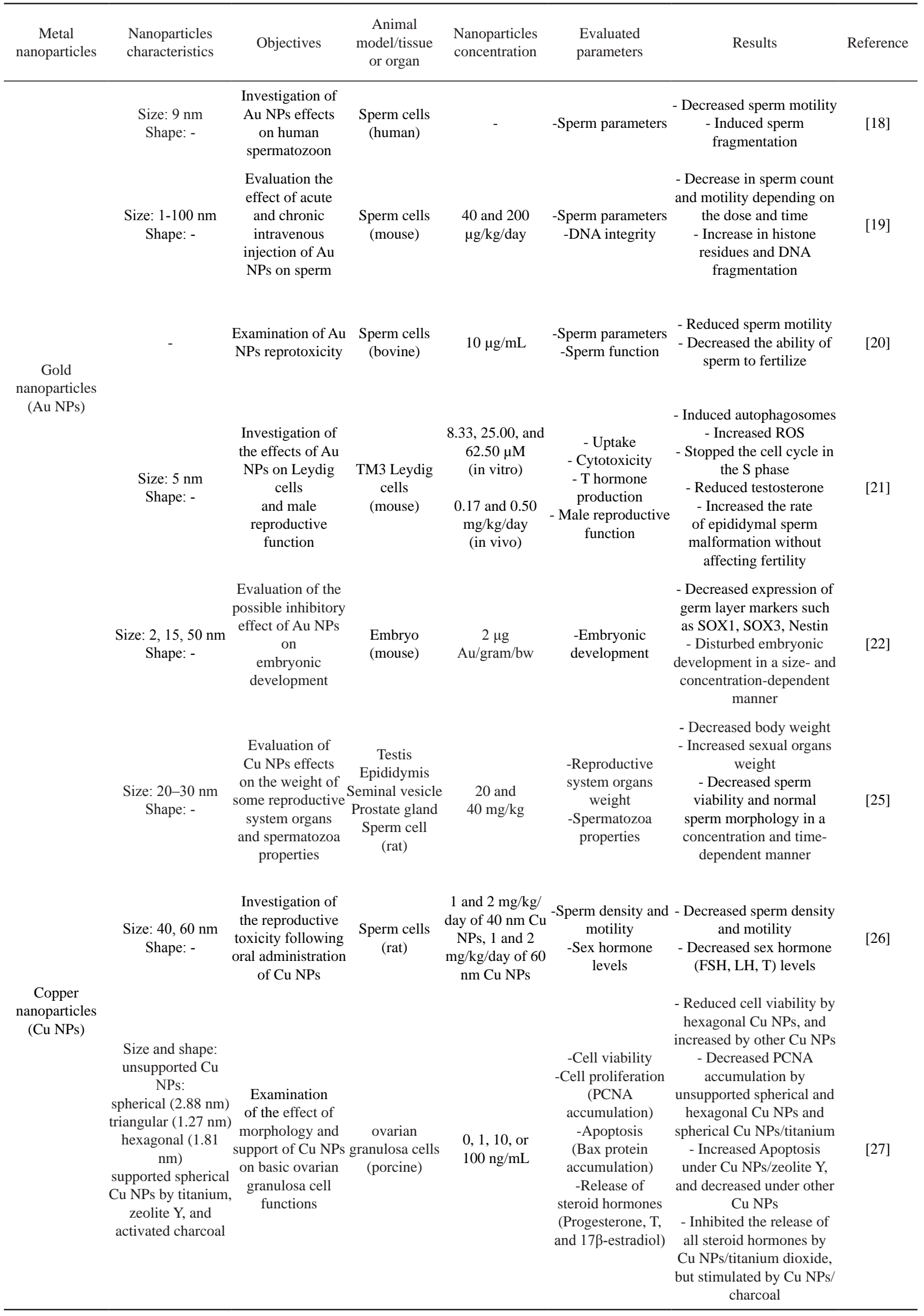




\begin{tabular}{cccccc}
\hline $\begin{array}{c}\text { Metal } \\
\text { nanoparticles }\end{array}$ & $\begin{array}{c}\text { Nanoparticles } \\
\text { characteristics }\end{array}$ & Objectives & $\begin{array}{c}\text { Animal } \\
\text { model/tissue } \\
\text { or organ }\end{array}$ & $\begin{array}{c}\text { Nanoparticles } \\
\text { concentration }\end{array}$ & $\begin{array}{c}\text { Evaluated } \\
\text { parameters }\end{array}$ \\
\hline
\end{tabular}

PEI and PAA Evaluation of -coated iron the Fe NPs with nanoparticles different surface (core size: charges effects on $12 \mathrm{~nm}$ ) pregnant mice

Investigation of short and longterm effects of positively and Size: $28 \mathrm{~nm}$ negatively charged Shape: $\mathrm{Fe}_{2} \mathrm{O}_{3} \mathrm{NPs}$ at low
and high doses during the main organogenesis period

\section{Uterine \\ Testis \\ Fetus \\ (mouse)}

10 and $100 \quad$-Organogenesis $\mathrm{mg} / \mathrm{kg} \quad$-Tissue histology
-Fetal death

- Positively charged PEI-coated nanoparticles increased post$10 \mathrm{mg} \mathrm{NPs} / \mathrm{kg}$ - Ability of NPs to implantation loss, reduced body mass cross the placenta maternal weight, cross the -Fetal liver toxicity placenta, and accumulated in the fetal liver
- Favorable effects of low doses such as reducing fetal death and increasing litter size - Thickening of the endometrium and loss of germ cells by $100 \mathrm{mg} / \mathrm{kg}$ PEI-coated nanoparticles
Size: $<50 \mathrm{~nm}$

Shape: -

Evaluation of testicular toxicity effect of $\mathrm{Fe}_{2} \mathrm{O}_{3} \mathrm{NPs}$

Testis (mouse)
Iron nanoparticles (Fe NPs)
Investigation of uncoated, silica-coated,

Size: $11 \mathrm{~nm}$ and PEGylated

Shape: silica-coated iron nanoparticles effects on cultured ovarian tissue

\footnotetext{
Examination

of BSA-coated

uperparamagnetic

nanoparticles

effect on granulosa

cells

Evaluation of bull sperm response under magnetic

fluid containing

DMSA-coated

maghemite

nanoparticles
(MNP-DMSA)
}

\begin{tabular}{|c|c|c|c|}
\hline & & $\begin{array}{l}\text {-Sperm motility } \\
\text {-Acrosome integrity }\end{array}$ & - No negative effects on \\
\hline $\begin{array}{l}\text { Sperm } \\
\text { (bull) }\end{array}$ & $\begin{array}{c}0.03,0.06,0.015 \\
\mathrm{mg} / \mathrm{mL}\end{array}$ & $\begin{array}{l}\text {-Cell membrane } \\
\text {-Sperm structure } \\
\text {-Uptake of } \\
\text { nanoparticles }\end{array}$ & $\begin{array}{c}\text { motility, viability and sperm } \\
\text { structure } \\
\text { - Inability of nanoparticles to } \\
\text { penetrate to the sperm }\end{array}$ \\
\hline
\end{tabular}

-ROS

antioxidant

25 and 50

enzymes activity

-Serum T level -Histopathological

study

- Increased ROS, lipid peroxidation, protein carbonyl content, glutathione peroxidase activity, and nitric oxide levels - Decreased SOD, catalase, glutathione, and vitamin C

- Increased Bax and caspase-3 expression

- Increased Serum T levels

- Vacuolization, detachment, and sloughing of germ cells

-Steroid hormone

Granulosa cells 10,25 , or $50 \mu \mathrm{g}$ / receptor expression (human) $\mathrm{mL}$-Granulosa cell

- No effect was observed viability
Ovary

Follicles

(sheep)
-Tissue structure

$10 \mathrm{mg} / \mathrm{mL}$ morphological

- Reduced penetration of particles into cells by PEGylated nanoparticles Follicular viability - Induced oxidative stress -Oxidative stress by uncoated nanoparticles -Particle resulting in more tissue damage permeability and follicular cells reduction 


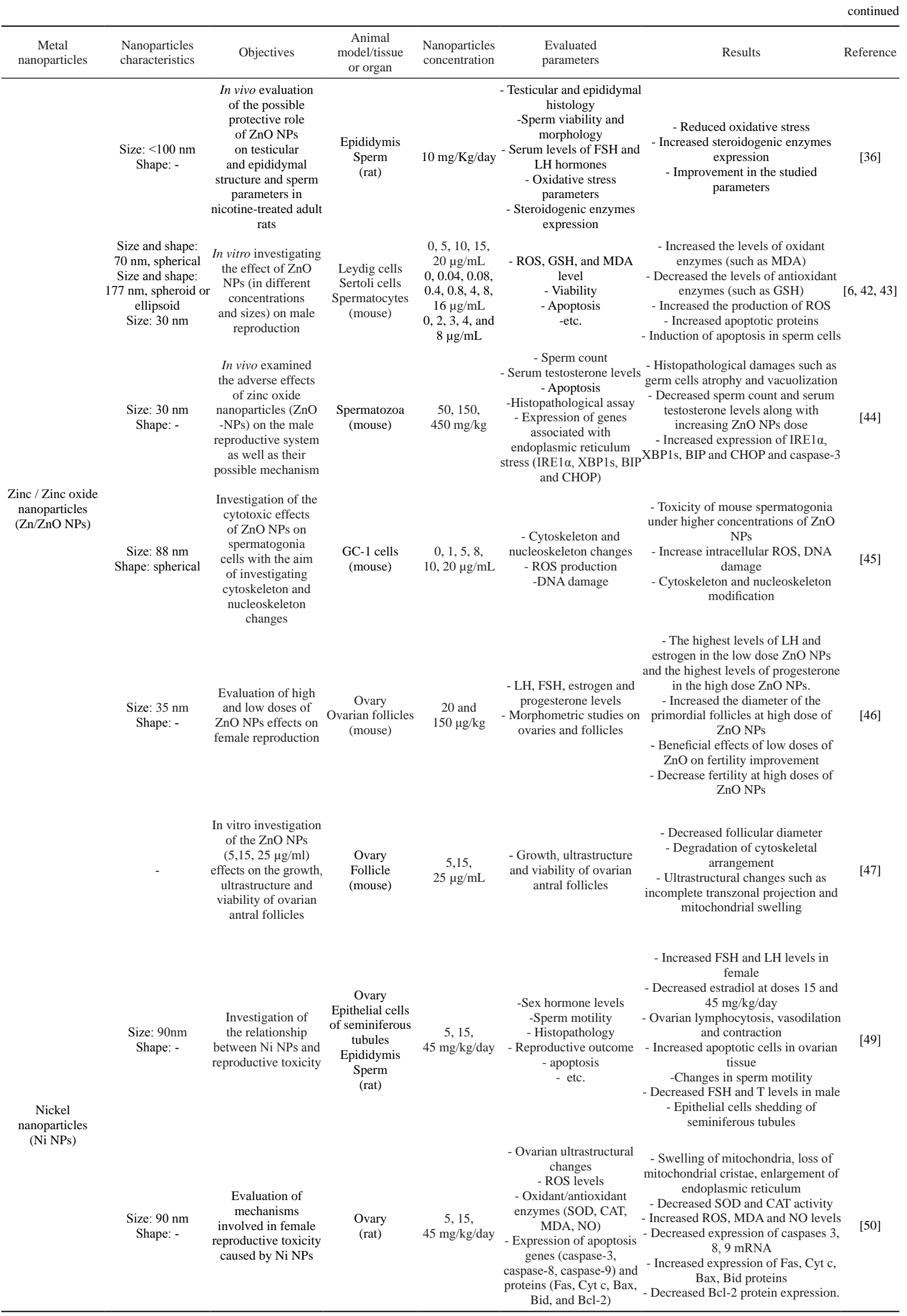


continued

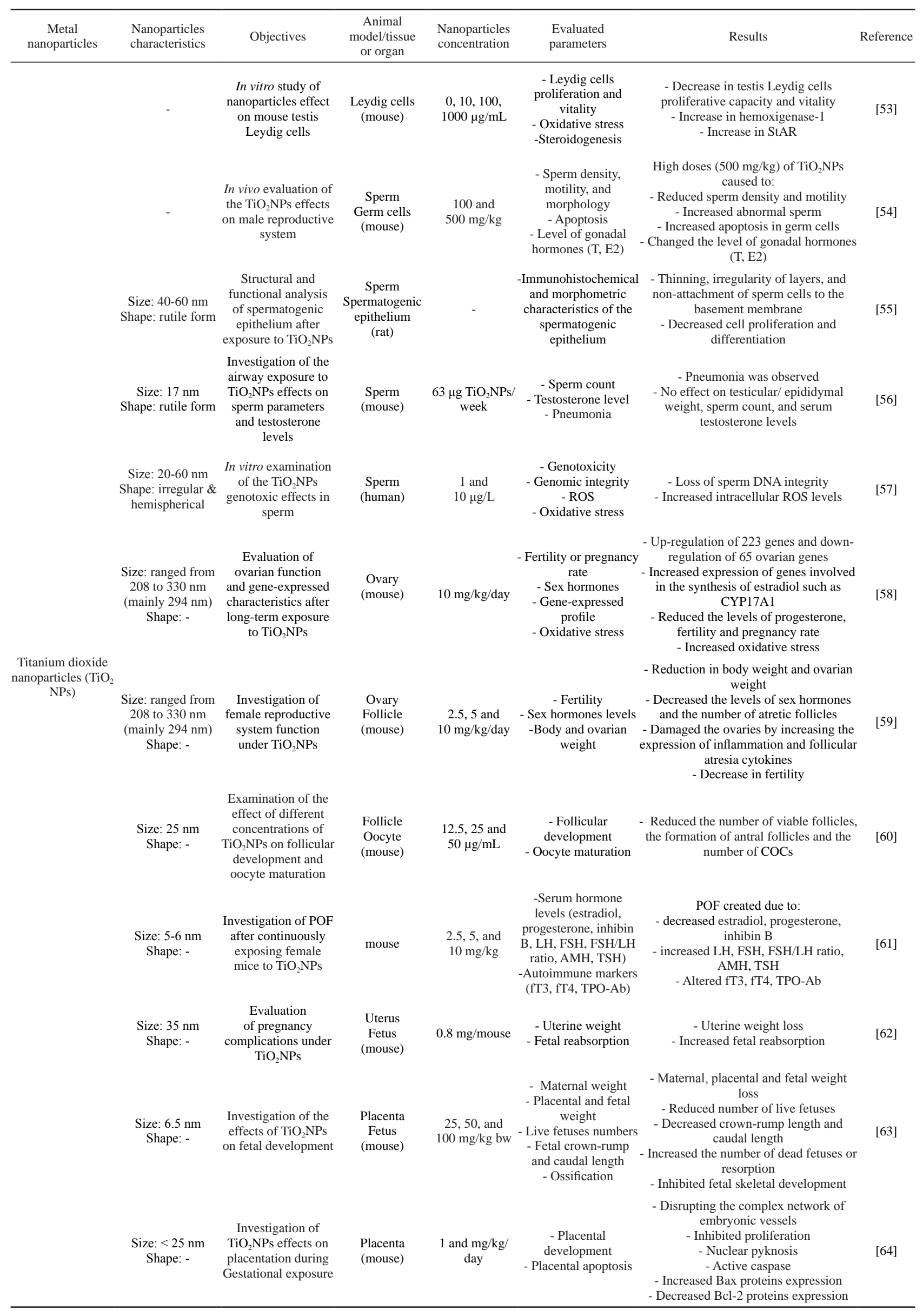




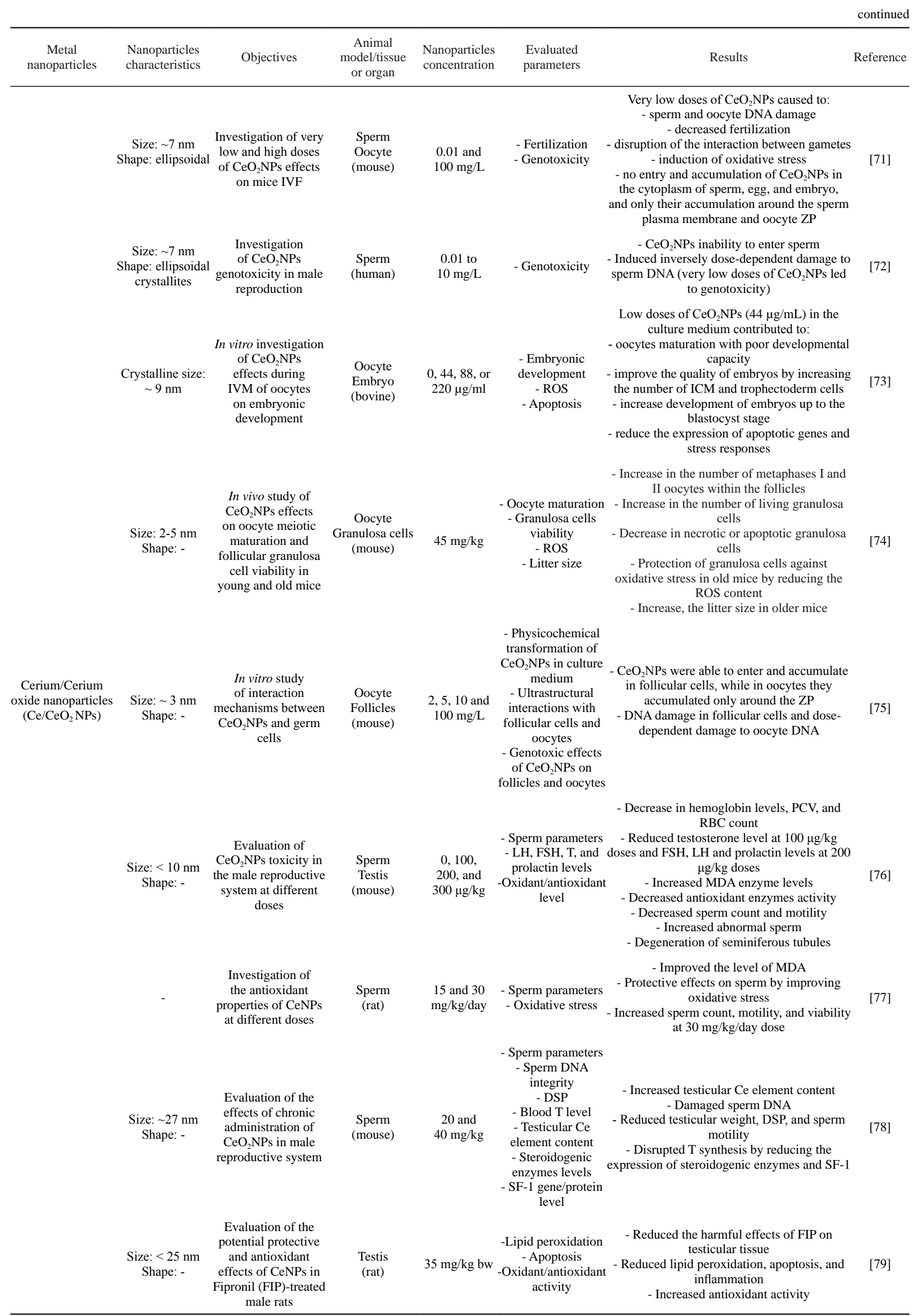




\section{Conclusions}

In summary, although most studies suggest that metal nanoparticles exhibit toxic effects when exposed to the reproductive system, some of them in low doses such as iron and cerium may lead to an improvement in the reproductive system as a supplement. Studies show that the shape, size, modification, surface charge, and administration method of nanoparticles affect their positive or negative performance, but there are deficiencies in this field, and the effect of them separately has not been well investigated. Although the mechanism of the effects of metal nanoparticles on the reproductive system has not been investigated completely, a few studies show that some of them can increase the efficiency of the system as micronutrients, which requires detailed and multifactorial studies.

\section{Acknowledgements}

The authors would like to thank Shiraz University of Medical Sciences, Shiraz, Iran and also Center for Development of Clinical Research of Nemazee Hospital and Dr. Nasrin Shokrpour for editorial assistance.

\section{Conflicts of Interest}

The authors have no conflicts of interest to declare that are relevant to the content of this article.

\section{References}

[1] G. Sangeetha, N. Usha, R. Nandhini, et al. A review on properties, applications and toxcities of metal nanoparticles. International Journal of Applied Pharmaceutics, 2020, 12(5): 58-63.

[2] W.I. Hagens, A.G. Oomen, W.H. de Jong, et al. What do we (need to) know about the kinetic properties of nanoparticles in the body? Regulatory toxicology and pharmacology, 2007, 49(3): 217-229.

[3] C.C. Hou, J.Q. Zhu. Nanoparticles and female reproductive system: how do nanoparticles affect oogenesis and embryonic development, Oncotarget, 2017, 8(65): 109799.

[4] Z. Lan, W.X. Yang. Nanoparticles and spermatogenesis: how do nanoparticles affect spermatogenesis and penetrate the blood-testis barrier. Nanomedicine, 2012, 7(4): 579-596.

[5] A.R. Pinho, S. Rebelo, Md.L. Pereira. The Impact of Zinc Oxide Nanoparticles on Male (In) Fertility. Materials, 2020, 13(4): 849.

[6] Q. Liu, C. Xu, G. Ji, et al. Sublethal effects of zinc oxide nanoparticles on male reproductive cells. Toxicology in Vitro, 2016, 35: 131-138.

[7] C. Muoth, L. Aengenheister, M. Kucki, et al. Nanoparticle transport across the placental barrier: pushing the field forward! Nanomedicine, 2016, 11(8): 941-957.

[8] S. Fournier, J. D'errico, P. Stapleton. Engineered nanomaterial applications in perinatal therapeutics. Pharmacological research, 2018; 130: 36-43.

[9] C. Graf, D.L. Vossen, A. Imhof, et al. A general method to coat colloidal particles with silica. Langmuir, 2003, 19(17): 6693-6700.

[10] N. Asare, C. Instanes, W.J. Sandberg, et al. Cytotoxic and genotoxic effects of silver nanoparticles in testicular cells. Toxicology, 2012, 291(1-3): 65-72.

[11] J.W. Han, J.K. Jeong, S. Gurunathan, et al. Male-and female-derived somatic and germ cell-specific toxicity of silver nanoparticles in mouse. Nanotoxicology, 2016, 10(3): 361-373.

[12] H. Kathem, M. Alwan. A study on toxic effects of silver nanoparticles on reproductive tract of male mice. J Anim Health Prod, 2019, 7(3): 85-91.

[13] N. Fathi, S.M. Hoseinipanah, Z. Alizadeh, et al. The effect of silver nanoparticles on the reproductive system of adult male rats: A morphological, histological and DNA integrity study. Advances in clinical and experimental medicine, 2019, 28(3): 299-305.

[14] J.L.M. de Brito, V.Nd. Lima, D.O. Ansa, et al. Acute reproductive toxicology after intratesticular injection of silver nanoparticles (Ag NPs) in Wistar rats. Nanotoxicology, 2020, 1-15.

[15] J.O. Olugbodi, O. David, E.N. Oketa, et al. Silver nanoparticles stimulates spermatogenesis impairments and hematological alterations in testis and epididymis of male rats. Molecules, 2020, 25(5): 1063.

[16] Y.C. Yeh, B. Creran, V.M. Rotello. Gold nanoparticles: preparation, properties, and applications in bionanotechnology. Nanoscale, 2012, 4(6): 1871-1880.

[17] S. Taghizadeh, V. Alimardani, P.L. Roudbali, et al. Gold nanoparticles application in liver cancer. Photodiagnosis and photodynamic therapy, 2019, 25: 389-400.

[18] V. Wiwanitkit, A. Sereemaspun, R. Rojanathanes. Effect of gold nanoparticles on spermatozoa: the first world report. Fertility and Sterility, 2009, 91(1): e7-e8.

[19] M. Nazar, A.R. Talebi, M.H. Sharifabad, et al. Acute and chronic effects of gold nanoparticles on sperm parameters and chromatin structure in Mice. International Journal of Reproductive BioMedicine, 2016, 14(10): 637-642.

[20] U. Taylor, A. Barchanski, S. Petersen, et al. Gold nanoparticles interfere with sperm functionality by membrane adsorption without penetration. Nanotoxicology, 2014, 8(sup1): 118-127.

[21] Y. Liu, X. Li, S. Xiao, et al. The effects of gold nanoparticles on Leydig cells and male reproductive function in mice. International Journal of Nanomedicine, 2020, 15: 9499-9514.

[22] X. Ma, X. Yang, Y. Wang, et al. Gold nanoparticles cause size-dependent inhibition of embryonic development during murine pregnancy. Nano Research, 2018, 11(6): 3419-3433.

[23] M. Ahamed, M.A. Siddiqui, M.J. Akhtar, et al. Genotoxic potential of copper oxide nanoparticles in human lung epithelial cells. Biochemical and biophysical research communications, 2010, 396(2): 578-583.

[24] S. Roychoudhury, S. Nath, P. Massanyi, et al. Copperinduced changes in reproductive functions: in vivo and in vitro effects. Physiological Research, 2016, 65(1): 11-22.

[25] G.A. Al-Bairuty, M.N. Taha. Effects of copper nanoparticles on reproductive organs of male albino rats. International Journal for Sciences and Technology, 2016, 143(4101): 1-8.

[26] T. Kalirawana, P. Sharma, S.C. Joshi. Reproductive Toxicity of Copper Nanoparticles in Male Albino Rats. Int J Pharma Res Health Sci, 2018, 6(1): 2258-2263. 
[27] A.V. Sirotkin, M. Radosová, A. Tarko, et al. Effect of morphology and support of copper nanoparticles on basic ovarian granulosa cell functions. Nanotoxicology, 2020: $1-13$.

[28] H. Wu, J.J. Yin, W.G. Wamer, et al. Reactive oxygen species-related activities of nano-iron metal and nano-iron oxides. Journal of Food and Drug Analysis, 2014, 22(1): 86-94.

[29] A. Ebrahiminezhad, A. Zare-Hoseinabadi, A.K. Sarmah, et al. Plant-mediated synthesis and applications of iron nanoparticles. Molecular biotechnology, 2018, 60(2): 154-168.

[30] K.R. Di Bona, Y. Xu, P.A. Ramirez, et al. Surface charge and dosage dependent potential developmental toxicity and biodistribution of iron oxide nanoparticles in pregnant CD-1 mice. Reproductive Toxicology, 2014, 50: 36-42.

[31] K.R. Di Bona, Y. Xu, M. Gray, L et al. Short-and long-term effects of prenatal exposure to iron oxide nanoparticles: influence of surface charge and dose on developmental and reproductive toxicity. International journal of molecular sciences, 2015, 16(12): 3025130268.

[32] K. Sundarraj, V. Manickam, A. Raghunath, et al. Repeated exposure to iron oxide nanoparticles causes testicular toxicity in mice. Environmental toxicology, 2017, 32(2): 594-608.

[33] M. Poettler, S. Hofmann, S. Duerr, et al. Effect of BSAcoated superparamagnetic iron oxide nanoparticles on granulosa cells. Anticancer Research, 2016, 36(6): 31473154.

[34] D.F. Caldeira, F. Paulini, R.C. Silva, et al. In vitro exposure of bull sperm cells to DMSA-coated maghemite nanoparticles does not affect cell functionality or structure. International Journal of Hyperthermia, 2018; 34(4): 415-422.

[35] S. Karimi, S.N. Tabatabaei, A.C. Gutleb, et al. The effect of PEGylated iron oxide nanoparticles on sheep ovarian tissue: An ex-vivo nanosafety study. Heliyon, 2020, 6(9): e04862.

[36] D.A. Mohamed, S.A. Abdelrahman. The possible protective role of zinc oxide nanoparticles (ZnONPs) on testicular and epididymal structure and sperm parameters in nicotine-treated adult rats (a histological and biochemical study). Cell and tissue research, 2019, 375(2): 543-558.

[37] A. Beigi Harchegani, H. Dahan, E. Tahmasbpour, et al. Effects of zinc deficiency on impaired spermatogenesis and male infertility: the role of oxidative stress, inflammation and apoptosis. Human Fertility, 2020, 23(1): 5-16.

[38] Y. Zhao, Y. Tan, J. Dai, et al. Exacerbation of diabetesinduced testicular apoptosis by zinc deficiency is most likely associated with oxidative stress, p38 MAPK activation, and p53 activation in mice. Toxicology letters, 2011, 200(1-2): 100-106.

[39] M. Vaseem, A. Umar, Y.B. Hahn. ZnO nanoparticles: growth, properties, and applications. Metal oxide nanostructures and their applications, 2010: 5(1).

[40] M. Zare, K. Namratha, K. Byrappa, et al. Surfactant assisted solvothermal synthesis of $\mathrm{ZnO}$ nanoparticles and study of their antimicrobial and antioxidant properties. Journal of materials science \& technology, 2018, 34(6): 1035-1043.

[41] S. Soren, S. Kumar, S. Mishra, et al. Evaluation of antibacterial and antioxidant potential of the zinc oxide nanoparticles synthesized by aqueous and polyol method. Microbial pathogenesis, 2018, 119: 145-151.

[42] Z. Han, Q. Yan, W. Ge, et al. Cytotoxic effects of ZnO nanoparticles on mouse testicular cells. International journal of nanomedicine, 2016, 11: 5187-5203.
[43] J. Shen, D. Yang, X. Zhou, et al. Role of autophagy in zinc oxide nanoparticles-induced apoptosis of mouse LEYDIG cells. International journal of molecular sciences, 2019, 20(16): 4042.

[44] Y. Tang, B. Chen, W. Hong, et al. ZnO Nanoparticles Induced Male Reproductive Toxicity Based on the Effects on the Endoplasmic Reticulum Stress Signaling Pathway. International Journal of Nanomedicine, 2019, 14: 95639576.

[45] A.R. Pinho, F. Martins, M.E.V. Costa, et al. In Vitro Cytotoxicity Effects of Zinc Oxide Nanoparticles on Spermatogonia Cells. Cells, 2020, 9(5): 1081.

[46] S.R. Ibraheem, M.R. Ibrahim. Physiological and histological effects of (zinc and iron) oxide nanoparticles on some fertility parameters in female mice. AlMustansiriyah Journal of Science, 2016, 27(5): 1-10.

[47] R. Santacruz-Márquez, A. Solorio-Rodríguez, S. González-Posos, et al. Comparative effects of $\mathrm{TiO}_{2}$ and $\mathrm{ZnO}$ nanoparticles on growth and ultrastructure of ovarian antral follicles. Reproductive Toxicology, 2020, 96: 399412.

[48] R.R. Magaye, X. Yue, B. Zou, et al. Acute toxicity of nickel nanoparticles in rats after intravenous injection. International journal of nanomedicine, 2014, 9: 13931402.

[49] L. Kong, M. Tang, T. Zhang, et al. Nickel nanoparticles exposure and reproductive toxicity in healthy adult rats. International journal of molecular sciences, 2014, 15(11): 21253-21269.

[50] L. Kong, X. Gao, J. Zhu, et al. Mechanisms involved in reproductive toxicity caused by nickel nanoparticle in female rats. Environmental toxicology, 2016, 31(11): 1674-1683.

[51] A. Weir, P. Westerhoff, L .Fabricius, et al. Titanium dioxide nanoparticles in food and personal care products. Environmental science \& technology, 2012, 46(4): 22422250.

[52] H. Shi, R. Magaye, V. Castranova, et al. Titanium dioxide nanoparticles: a review of current toxicological data. Particle and fibre toxicology, 2013, 10(1): 15.

[53] T. Komatsu, M. Tabata, M. Kubo-Irie, et al. The effects of nanoparticles on mouse testis Leydig cells in vitro. Toxicology in vitro, 2008, 22(8): 1825-1831.

[54] L. Guo, X.H. Liu, D. Qin, et al. Effects of nanosized titanium dioxide on the reproductive system of male mice. Zhonghua nan ke xue= National journal of andrology, 2009, 15(6): 517-522.

[55] L. Sharafutdinova, A. Fedorova, S. Bashkatov, et al. Structural and functional analysis of the spermatogenic epithelium in rats exposed to titanium dioxide nanoparticles. Bulletin of experimental biology and medicine, 2018, 166(2): 279-282.

[56] A.J. Lauvås, A. Skovmand, M.S. Poulsen, et al. Airway exposure to $\mathrm{TiO}_{2}$ nanoparticles and quartz and effects on sperm counts and testosterone levels in male mice. Reproductive Toxicology, 2019, 90: 134-140.

[57] M. Santonastaso, F. Mottola, N. Colacurci, et al. In vitro genotoxic effects of titanium dioxide nanoparticles $\left(\mathrm{n}-\mathrm{TiO}_{2}\right)$ in human sperm cells. Molecular reproduction and development, 2019, 86(10): 1369-1377.

[58] G. Gao, Y. Ze, B. Li, et al. Ovarian dysfunction and geneexpressed characteristics of female mice caused by longterm exposure to titanium dioxide nanoparticles. Journal of hazardous materials, 2012, 243: 19-27.

[59] X. Zhao, Y. Ze, G. Gao, et al. Nanosized $\mathrm{TiO}_{2}$-induced reproductive system dysfunction and its mechanism in female mice. Plos one, 2013, 8(4): e59378.

[60] J. Hou, X. Wan, F. Wang,. Effects of titanium dioxide nanoparticles on development and maturation of rat preantral follicle in vitro. Academic Journal of Second 
Military Medical University. 2009, 30(8): 869-873.

[61] F. Hong, L. Wang. Nanosized titanium dioxide-induced premature ovarian failure is associated with abnormalities in serum parameters in female mice. International journal of nanomedicine. 2018, 13: 2543.

[62] K. Yamashita, Y. Yoshioka, K. Higashisaka, et al. Silica and titanium dioxide nanoparticles cause pregnancy complications in mice. Nature nanotechnology. 2011, 6(5): 321-328

[63] F. Hong, Y. Zhou, X. Zhao, et al. Maternal exposure to nanosized titanium dioxide suppresses embryonic development in mice. International journal of nanomedicine, 2017, 12: 6197-6204.

[64] L. Zhang, X. Xie, Y. Zhou, et al. Gestational exposure to titanium dioxide nanoparticles impairs the placentation through dysregulation of vascularization, proliferation and apoptosis in mice. International journal of nanomedicine, 2018, 13: 777-789.

[65] J. Emsley, Nature's building blocks: an AZ guide to the elements. Oxford University Press, 2011.

[66] M. Jakupec, P. Unfried, B. Keppler. Pharmacological properties of cerium compunds. Reviews of physiology, biochemistry and pharmacology, Springer, 2005: 101111.

[67] J.T. Dahle, Y. Arai. Environmental geochemistry of cerium: applications and toxicology of cerium oxide nanoparticles. International journal of environmental research and public health, 2015, 12(2): 1253-1278.

[68] K. Reed, A. Cormack, A. Kulkarni, et al. Exploring the properties and applications of nanoceria: is there still plenty of room at the bottom? Environmental Science: Nano, 2014, 1(5): 390-405.

[69] V.C. Minarchick, P.A. Stapleton, D.W. Porter, et al. Pulmonary cerium dioxide nanoparticle exposure differentially impairs coronary and mesenteric arteriolar reactivity. Cardiovascular toxicology, 2013, 13(4): 323337.

[70] R.W. Tarnuzzer, J. Colon, S. Patil, et al. Vacancy engineered ceria nanostructures for protection from radiation-induced cellular damage. Nano letters, 2005, 5(12): 2573-2577.

[71] L. Preaubert, B. Courbiere, V. Achard, et al. Cerium dioxide nanoparticles affect in vitro fertilization in mice. Nanotoxicology, 2016, 10(1): 111-117.

[72] L. Préaubert, V. Tassistro, M. Auffan, et al. Very low concentration of cerium dioxide nanoparticles induce DNA damage, but no loss of vitality, in human spermatozoa. Toxicology in Vitro, 2018, 50: 236-241.

[73] F. Ariu, L. Bogliolo, A. Pinna, et al. Cerium oxide nanoparticles $\left(\mathrm{CeO}_{2} \mathrm{NPs}\right)$ improve the developmental competence of in vitro-matured prepubertal ovine oocytes. Reproduction, Fertility and Development, 2017, 29(5): 1046-1056.

[74] N.Y. Spivak, E. Shepel, N. Zholobak, et al. Ceria nanoparticles boost activity of aged murine oocytes. Nano Biomedicine \& Engineering, 2012, 4(4): 188-194.

[75] B. Courbiere, M. Auffan, R. Rollais, et al. Ultrastructural interactions and genotoxicity assay of cerium dioxide nanoparticles on mouse oocytes. International journal of molecular sciences, 2013, 14(11): 21613-21628.

[76] O. Adebayo, O. Akinloye, O. Adaramoye. Cerium oxide nanoparticle elicits oxidative stress, endocrine imbalance and lowers sperm characteristics in testes of balb/c mice. Andrologia, 2018, 50(3): e12920.

[77] H. Moridi, S.A. Hosseini, H. Shateri, et al. Protective effect of cerium oxide nanoparticle on sperm quality and oxidative damage in malathion-induced testicular toxicity in rats: An experimental study. International journal of reproductive biomedicine, 2018, 16(4): 261-266.

[78] F. Qin, T. Shen, J. Li, et al. SF-1 mediates reproductive toxicity induced by Cerium oxide nanoparticles in male mice. Journal of nanobiotechnology, 2019, 17(1): 1-13.

[79] H. Saleh, A.M. Nassar, A.E. Noreldin, et al. ChemoProtective Potential of Cerium Oxide Nanoparticles against Fipronil-Induced Oxidative Stress, Apoptosis, Inflammation and Reproductive Dysfunction in Male White Albino Rats. Molecules, 2020, 25(15): 3479.

Copyright $₫$ Parvin Lohrasbi, Soghra Bahmanpour. This is an open-access article distributed under the terms of the Creative Commons Attribution License, which permits unrestricted use, distribution, and reproduction in any medium, provided the original author and source are credited. 